\title{
Botulinum toxin therapy in the SARS-CoV-2 pandemic: patient perceptions from a German cohort
}

\author{
Dirk Dressler $^{1}$ (D) Fereshte Adib Saberi ${ }^{2}$
}

Received: 26 June 2020 / Accepted: 16 July 2020 / Published online: 30 July 2020

(c) The Author(s) 2020

\begin{abstract}
The SARS-CoV-2 virus pandemic has provoked drastic countermeasures including shutdowns of public services. We wanted to describe the effects of a 6 week shutdown of a large German botulinum toxin (BT) outpatient clinics on patients and their well-being. 45 patients (age 61.9 \pm 9.8 years, 29 females, 16 males) receiving BT therapy $(319.3 \pm 201.9$ MU-equivalent, treatment duration $8.3 \pm 5.5$ years) were surveyed with a standardised questionnaire. The shutdown delayed BT therapy by $6.6 \pm 2.3$ weeks. $93 \%$ of the patients noticed increased muscle cramps and $82 \%$ increased pain reducing their quality of life by $40.2 \pm 19.5 \%$. For 23 patients with cervical dystonia this reduction was $41.1 \pm 18.3 \%$, for 3 patients with blepharospasm $33.3 \pm 15.3 \%$, for 9 patients with spasticity $37.8 \pm 15.6 \%$, for 4 patients with pain conditions $37.4 \pm 35.7 \%$ and for 3 patients with hemifacial spasm $27.5 \pm 17.1 \%$. After the shutdown $66 \%$ of patients perceived BT therapy as more important than before, $32 \%$ perceived it as unchanged. For all patients long-term availability of BT therapy was very important or important. $98 \%$ of the patients perceived the shutdown as inadequate and felt their patient rights not respected. The shutdown confirmed the considerable burden of disease caused by dystonia, spasticity, hemifacial spasm and various pain conditions and the importance of BT therapy to treat them. Any shutdown severely affects these patients and needs to be avoided.
\end{abstract}

Keywords Botulinum toxin · Therapy · Corona virus · SARS-CoV-2 · COVID19 · Pandemic · Dystonia - Spasticity · Hemifacial spasms $\cdot$ Pain conditions $\cdot$ Quality of life $\cdot$ Perception $\cdot$ Patient rights

\section{Introduction}

The corona crisis, the SARS-CoV-2 (corona) virus pandemic producing the clinical picture of COVID19, has hit virtually all health care systems worldwide with dramatic impact. Drastic corona virus countermeasures have been installed to deal with it. Many of them have deeply affected social and economic interactions, whilst others have affected the health care systems themselves. We wanted to describe how these countermeasures have affected patients receiving botulinum toxin (BT) therapy in Germany.

Dirk Dressler

dressler.dirk@mh-hannover.de

1 Movement Disorders Section, Department of Neurology, Hannover Medical School, Carl-Neuberg-Str. 1, 30625 Hannover, Germany

2 IAB-Interdisciplinary Working Group for Movement Disorders, Hamburg, Germany

\section{Methods}

\section{Design}

The study is a survey of the effects of a 6 week BT outpatient clinics shutdown on its patients and their wellbeing. It is based on a face-to-face interview using the structuralised questionnaire shown in Table 1. Before presenting the questionnaire, patients were informed about the initiative of the ministry of health, its intention and its execution by Hannover Medical School and the Department of Neurology resulting in several countermeasures including a general shutdown of the BT outpatient clinics. The study was approved by the local ethics committee.

\section{Treatment institution}

The study was performed at the Movement Disorders Section, Department of Neurology, Hannover Medical School, Hannover, Germany which was founded 11 years ago by one of the authors (DD) and is specialised in BT therapy. 
Table 1 Structuralised questionnaire to survey the effects of the anti-corona virus shutdown on patients receiving BT therapy

Symptoms caused by shutdown

Reduction of quality of life caused by shutdown (pls. estimate overall percentage)

Change of perception of BT therapy caused by shutdown

Perception of long-term BT treatment security

Perception of the anti-corona shutdown

Respect of your patient rights
Increased muscle cramps

Increased muscle pain

Perceive BT therapy as more important than before

No change in perception

Perceive BT therapy as less important than before

Very important

Important

Less important

Inadequate

Adequate

Not respected by shutdown

Respected by shutdown

Translation from German

$B T$ botulinum toxin

Currently, its annual BT usage is equivalent to more than 20,000 100MU vials of all major brands available in Germany.

\section{Patients}

Patients were consecutively included in this study until the pre-set number of participants of 45 was reached. Patients had to fit the following inclusion criteria: (1) BT therapy delay due to the shutdown of more than 2 weeks. (2) BT therapy for more than 1 year. (3) Regular subjective global improvement induced by BT therapy $>30 \%$. (4) No additional stress events after the last BT injection series. (5) Ability to understand and to react adequately to the questionnaire. The patient's participation in this survey was entirely voluntary. None of the patients invited declined their participation.

\section{BT therapy}

BT therapy was performed with onabotulinumtoxinA (ONA, Botox ${ }^{\circledR}$, Allergan GmbH, Frankfurt/M, Germany) (100MU in $2.5 \mathrm{ml} 0.9 \% \mathrm{NaCl} / \mathrm{H}_{2} \mathrm{O}$ ) incobotulinumtoxinA (INCO, Xeomin ${ }^{\circledR}$, Merz Pharmaceuticals, Frankfurt/M Germany) (100MU in $2.5 \mathrm{ml} 0.9 \% \mathrm{NaCl} / \mathrm{H}_{2} \mathrm{O}$ ), or abobotulinumtoxin A (ABO, Dysport ${ }^{\circledR}$, Ipsen Pharma GmbH, Munich, Germany) (500MU in $5.0 \mathrm{ml} 0.9 \% \mathrm{NaCl} / \mathrm{H}_{2} \mathrm{O}$ ). For comparison reasons equivalence mouse units (MU-E) were introduced. 1MU-E was equal $1 \mathrm{MU}$ of ONA and $1 \mathrm{MU}$ of INCO and $3 \mathrm{MU}$ of ABO. BT therapy is available to all patients at no costs except for a small nominal drug delivery charge. There is maximal freedom to determine interinjection intervals and BT doses.

\section{Corona virus countermeasures}

Since early March 2020 the SARS-CoV-2 virus pandemic puzzled the public in Germany more and more. On March 17th 2020 the State of Lower Saxony Ministry of Health (Niedersächsisches Ministerium für Soziales, Gesundheit und Gleichstellung) ordered all hospitals [...] to stop all un-initiated non-urgent medical procedures (Niedersächsische Verordnung zur Bekämpfung der Corona-VirusKrankheit COVID-19) (Niedersächsisches Gesetz- und Verordnungsblatt 2020a). This was meant to release capacities for treatment of COVID patients and to reduce general infection risks. 6 weeks later, on May 5th this order was de-activated (Niedersächsisches Gesetz- und Verordnungsblatt 2020b). Referring to this order the Chairman of the Department of Neurology of Hannover Medical School closed the BT outpatient clinics (shutdown). Patients were informed that the clinics were closed for an unforeseeable period of time and that they should re-apply for an appointment again at a later point of time.

\section{Results}

\section{Patients}

As shown in Table 2, altogether 45 patients (age $61.9 \pm 9.8$ years, 29 females, 16 males) were included in this study. 23 patients suffered from cervical dystonia, 3 from blepharospasm, 9 from spasticity, 4 from pain conditions, 3 from hemifacial spasm. 
Table 2 Patient demographics and botulinum toxin treatment data

\begin{tabular}{ll}
\hline Total number of patients $[n]$ & 45 \\
Male patients $[n]$ & 16 \\
Female patients $[n]$ & 29 \\
Patient age (mean \pm standard deviation) [years] & $61.9 \pm 9.8$ \\
Indication for BT therapy [ $n]$ & Cervical dystonia: 23 \\
& Blepharospasm: 3 \\
& Spasticity: 9 \\
& Pain: 4 \\
BT drug & Hemifacial spasm: 3 \\
& AbobotulinumtoxinA: 3 \\
BT total equivalent dose (mean \pm standard deviation) [MU-E] & IncobotulinumtoxinA: 30 \\
Treatment duration (mean \pm standard deviation) [years] & OnabotulinumtoxinA: 12 \\
Interinjection interval (mean \pm standard deviation) [weeks] & $319.3 \pm 201.9$ \\
Subjective global improvement induced by BT therapy (mean \pm standard devia- & $67.2 \pm 16.2$ \\
tion) [\%] & $8.3 \pm 5.5$ \\
\hline
\end{tabular}

$1 \mathrm{MU}-\mathrm{E}=1 \mathrm{MU}$-onabotulinumtoxin $\mathrm{A}=1 \mathrm{MU}$-incobotulinumtoxin $\mathrm{A}=0.5 \mathrm{MU}$-abobotulinumtoxin $\mathrm{A}$

$B T$ botulinum toxin, $M U-E$ equivalent mouse units

\section{BT therapy}

As shown in Tables 2, 3 patients received ABO, 30 INCO and 12 ONA. Their BT total doses were 319.3 $\pm 201.9 \mathrm{MU}-\mathrm{E}$ (min. 24MU-E, max. 900MU-E). They had been treated with BT therapy for $8.3 \pm 5.5$ years. Before the shutdown BT therapy was applied at intervals of $11.2 \pm 1.3$ weeks. The BT-induced improvement was $67.2 \pm 16.2 \%$.

\section{Shutdown effects}

Table 3 shows the effects of the shutdown on the patients and their well-being. As the result of the shutdown, the interinjection intervals increased from 11.2 \pm 1.3 weeks to $17.7 \pm 2.4$ weeks delaying BT therapy by $6.6 \pm 2.3$ weeks. The minimum delay was (by definition) 2 weeks, the maximum delay 12 weeks. $93 \%$ of the patients noticed increased muscle cramps and $82 \%$ increased muscle pain. Due to the shutdown, the patient's quality of life was reduced by $40.2 \pm 19.5 \%$. For patients with cervical dystonia this reduction was $41.1 \pm 18.3 \%$, for patients with blepharospasm $33.3 \pm 15.3 \%$, for patients with spasticity $37.8 \pm 15.6 \%$, for patients with pain condition $37.4 \pm 35.7 \%$ and for patients with hemifacial spasm $27.5 \pm 17.1 \%$. After the shutdown $66 \%$ of patients perceived BT therapy as more important than before. For $32 \%$ of patients the perception of BT therapy was unchanged. One patient $(2 \%)$ considered BT therapy as less important after the shutdown, perceived the shutdown as adequate and felt her patient rights adequately respected. $91 \%$ of patients perceived long-term security of BT therapy availability as very important, $9 \%$ as important and none as less important. $98 \%$ of the patients perceived
Table 3 Effects of the botulinum toxin outpatient clinics shutdown on the patients and their well-being

\begin{tabular}{|c|c|}
\hline $\begin{array}{l}\text { Delay of re-treatment (mean } \pm \text { standard deviation) } \\
\text { [weeks] }\end{array}$ & $6.6 \pm 2.3$ \\
\hline \multicolumn{2}{|l|}{ Symptoms caused by shutdown } \\
\hline Increased muscle cramps [\% of patients] & 93 \\
\hline Increased muscle pain [\% of patients] & 82 \\
\hline \multicolumn{2}{|l|}{ Reduction of quality of life caused by shutdown } \\
\hline $\begin{array}{l}\text { All indications }(n=45)(\text { mean } \pm \text { standard deviation }) \\
{[\%]}\end{array}$ & $40.2 \pm 19.5$ \\
\hline $\begin{array}{l}\text { Cervical dystonia }(n=23)(\text { mean } \pm \text { standard deviation }) \\
{[\%]}\end{array}$ & $41.1 \pm 18.3$ \\
\hline Blepharospasm $(n=3)($ mean \pm standard deviation $)[\%]$ & $33.3 \pm 15.3$ \\
\hline Spasticity $(n=9)($ mean \pm standard deviation) [\%] & $37.8 \pm 15.6$ \\
\hline Pain conditions $(n=4)($ mean \pm standard deviation) $[\%]$ & $37.4 \pm 35.7$ \\
\hline $\begin{array}{l}\text { Hemifacial spasm }(n=4)(\text { mean } \pm \text { standard deviation }) \\
{[\%]}\end{array}$ & $27.5 \pm 17.1$ \\
\hline \multicolumn{2}{|l|}{ Change of perception of BT therapy caused by shutdown } \\
\hline $\begin{array}{l}\text { BT therapy is more important than before [\% of } \\
\text { patients] }\end{array}$ & 66 \\
\hline No change [\% of patients] & 32 \\
\hline BT therapy is less important than before [\% of patients] & 2 \\
\hline \multicolumn{2}{|l|}{ Perception of long-term BT treatment security } \\
\hline Very important $[\%$ of patients] & 91 \\
\hline Important [\% of patients] & 9 \\
\hline Less important [\% of patients] & 0 \\
\hline \multicolumn{2}{|l|}{ Perception of shutdown } \\
\hline Inadequate [\% of patients] & 98 \\
\hline Adequate [\% of patients] & 2 \\
\hline \multicolumn{2}{|l|}{ Respect of your patient's rights } \\
\hline Not respected [\% of patients] & 98 \\
\hline Respected [\% of patients] & 2 \\
\hline
\end{tabular}


the shutdown as inadequate and felt that their patient rights were not respected.

\section{Discussion}

The corona crisis has provoked numerous countermeasures. One of the most invasive ones are shutdowns, especially when they affect medical services. There have been several occasions when medical services were shutdown in the past. They included trade union actions, natural disasters, computer virus attacks and war activities. Never before, however, have medical service shutdowns lasted so long and have they affected such a variety of services and such large geographical areas. This massive impact should have produced signals strong enough for various analyses including the relevance of the treated disorders and the BT therapy offered.

In our study the shutdown increased the interinjection intervals from $11.2 \pm 1.3$ to $17.7 \pm 2.4$ weeks delaying BT therapy by $6.6 \pm 2.3$ weeks. In $38 \%$ of patients the delay was more than the actual duration of the shutdown as re-scheduling of these patients was problematic with the reduced capacity of the re-opened BT outpatient clinics. With BT's natural time course of action (Dressler and Adib Saberi 2005) this delay will have washed out most of BT's biological activity. Subsequently, the patient's quality of life during this period was reduced by $40.2 \pm 19.5 \%$. There were no apparent differences between the different indications. This means that even indications such as hemifacial spasm which may be perceived as less severe may produce a reduction of quality of life similar to indications which may have been perceived as more sever such as cervical dystonia or spasticity. More specifically and depending on the treated indication muscle hyperactivity and muscle pain have re-occurred during the shutdown in almost all patients.

Sixty-six percent of patients perceived their BT therapy as more important than before the shutdown experience. In $32 \%$ of patients the shutdown experience confirmed the patients' perception of the importance of their BT therapy. One patient (2\%) reported a lack of worsening of her cervical dystonia. She felt she may not need their BT therapy any more. Careful re-evaluation indicated that her mild cervical dystonia had recently improved and that the indication for her treatment has become relative, thus underlining the importance of occasional re-evaluations of patients receiving chronic BT therapy.

All patients expressed that the security of long-term availability of their BT therapy was very important or important.
Contrary to the patient's assumptions and expectations this security was obviously not provided by a large tertiary referral centre. Several patients expressed their disappointment about this fact.

Ninety-eight percent of patients felt their patient rights not respected. It is irritating that decision makers are not perceiving dystonia, spasticity and certain pain conditions as not severe enough to trigger treatment. Respective patient groups may use this information to intensify their advocacy and public awareness efforts in the future.

The shutdown confirmed the considerable burden of disease caused by dystonia, spasticity, hemifacial spasm and various pain conditions and the importance of BT therapy to treat them. Interrupting this therapy for whatever reason may generate substantial reductions in their well-being. Any shutdown of BT therapy may severely affect patients and needs to be avoided.

Acknowledgements Open Access funding provided by Projekt DEAL. This study was made possible by an unrestricted educational grant from IAB - Interdisciplinary Working Group for Movement Disorders.

Open Access This article is licensed under a Creative Commons Attribution 4.0 International License, which permits use, sharing, adaptation, distribution and reproduction in any medium or format, as long as you give appropriate credit to the original author(s) and the source, provide a link to the Creative Commons licence, and indicate if changes were made. The images or other third party material in this article are included in the article's Creative Commons licence, unless indicated otherwise in a credit line to the material. If material is not included in the article's Creative Commons licence and your intended use is not permitted by statutory regulation or exceeds the permitted use, you will need to obtain permission directly from the copyright holder. To view a copy of this licence, visit http://creativecommons.org/licenses/by/4.0/.

\section{Reference}

Dressler D, Adib Saberi F (2005) Botulinum toxin: mechanisms of action. Eur Neurol 53:3-9

Niedersächsisches Gesetz- und Verordnungsblatt (2020a) Niedersächsische Verordnung zur Bekämpfung der Corona-Virus-Krankheit COVID-19. 21067 (neu). Niedersächsisches Gesetz- und Verordnungsblatt, 74. Jahrgang, Nummer 4, 19.03.20, S:37-37

Niedersächsisches Gesetz- und Verordnungsblatt (2020b) Niedersächsische Verordnung zur Bekämpfung der Corona-Virus-Krankheit COVID-19. 21067. Niedersächsisches Gesetz- und Verordnungsblatt, 74. Jahrgang, Nummer 12, 05.05.20, S:90-93

Publisher's Note Springer Nature remains neutral with regard to jurisdictional claims in published maps and institutional affiliations. 